\title{
Morbidity profile of Preschool children in a rural community of Shimoga, Karnataka
}

\author{
Vijaykumar Mane ${ }^{1, *}$, M.V Sagar ${ }^{2}$, Revathy. $\mathbf{R}^{3}$ \\ ${ }^{\mathbf{1}}$ Assistant Professor, Dept. of Community Medicine, Koppal Institute of Medical Sciences, Koppal, Karnataka, ${ }^{2}$ Professor, Dept. \\ of Community Medicine, Subbaiah Institute of Medical Sciences, Shimoga, Karnataka, ${ }^{3}$ Biostatistician, Dept. of Community \\ Medicine, Shimoga Institute of Medical Sciences, Shimoga, Karnataka, India
}

*Corresponding Author:

Email: vijaymane01@gmail.com

\begin{abstract}
Introduction: Ensuring healthy growth and development of children should be a prime concern of all the countries as they are the future citizens of a country. Preschool children represents the most vulnerable group and they suffer from highest morbidity. There are geographical differences in the nature and extent of morbidities highlighting the need for area specific strategies and interventions.

Materials and Methods: A community based cross-sectional study was conducted for a duration of one year from January 2013 to December 2013 in the catchment area of PHC Aaynoor, Shimoga, Karnataka. Cluster sampling technique was used for sample selection and 400 preschool children were included by house to house visit. Data was collected using a pretested and semi structured questionnaire by interviewing the mothers/guardian. Data thus obtained were entered and analyzed using WHO Epi-info software version 3.5.4.

Results: The prevalence of morbidity among study subjects was $20.25 \%$. Acute respiratory infections were the most common morbidities affecting majority of the preschool children. Morbidity was found to be significantly associated with age, number of siblings and the paternal literacy of the child.

Conclusion: The present study findings may have important implications for policy-makers and planners seeking to improve child health.
\end{abstract}

Keywords: Preschool child, Morbidity, Age, Literacy.

\section{Introduction}

Children represent the future, and ensuring their healthy growth and development ought to be a prime concern of all the societies. Childhood is the period when the foundation for physical, psychological and social development of a human being are laid. The first few years of life represents the most crucial period as during this age there will be accelerated growth and development in the child, which warrants regular monitoring and any adverse influences occurring during this period may result in severe limitations in their development. ${ }^{1,2}$

Preschool children constitute approximately $15 \%$ of the country's population and are the most vulnerable group which suffers from highest morbidity. These children represent a transition from infancy when the child is protected physically and physiologically by the mother and it is this period during which about $40 \%$ of physical growth and $80 \%$ of mental development occurs. This age group is most affected by various common and easily treatable illnesses. ${ }^{3,4}$

Globally, the under-five mortality rate has decreased in the last few decades from 91 in 1990 to 43 deaths per 1000 live births in 2015 . However, still many countries have very high rates, and there is a huge disparity in child mortality between high-income and low-income countries. ${ }^{5}$ India alone accounted for one-fifth of all under-five deaths with 48 deaths per 1000 live births in the year 2015. More than half of these deaths were due to diseases that are either preventable or treatable through simple, affordable interventions. ${ }^{6}$
There are wide variations in morbidity pattern among under-five children in different countries. Infectious diseases like "acute respiratory infections", "Diarrhea", malaria and whooping cough have been found to be the leading causes of morbidity and premature death in developing countries like India. Three in four episodes of childhood illness are caused by one of these conditions or a combination of them. ${ }^{4}$ Even within India, there are geographical differences in the nature and extent of morbidities highlighting the need for area specific strategies and interventions. With this background, the present study was undertaken to study the morbidity pattern among preschool children in the study setting and its association with some selected variables.

\section{Objectives of the Study}

1. To estimate the prevalence and pattern of morbidities among preschool children in the study setting.

2. To determine the various factors associated with morbidity in children.

\section{Materials and Methods}

A community-based cross-sectional study was conducted for a duration of one year from January 2013 to December 2013 in the catchment area of PHC Aaynoor which is the rural field practice area of Shimoga Institute of Medical sciences, Shimoga, Karnataka. Ethical clearance for the study was obtained from Institutional Ethics Committee, SIMS, Shimoga. 
Minimum sample size calculated was 390 with an absolute precision of $7 \%$ and a significance level of 0.05 and design effect of 2 , taking $54 \%$ prevalence of morbidity from a previous study. ${ }^{4}$ Cluster sampling technique was used for subject selection. There were four subcentres under PHC Aaynoor and each subcenter was considered as a cluster. In order to have a representative sample, it was decided to include 100 preschool children from each of the four sub centers to make a total sample size of 400 . In each sub-Centre, one village was selected by simple random sampling. House to house visit was done and all the pre-school children of either sex were included for the study. The neighboring villages were also included for sample selection till a target of 100 pre-school children for that sub center was reached. Preschool children who were temporary visitors to the house, those who were not found in the house even after giving two visits and those residing in the study area for a duration of less than 6 months were excluded from the study.

Data about the socio-demographic profile, immunization history, history of current morbidity in the child and other relevant data were collected using a pretested and semi-structured questionnaire by interviewing mothers/guardian after taking an informed consent. Preschool children suffering from minor ailments were given treatment at their home itself while those with major illnesses were referred to nearest health center for management. Data thus obtained were entered and analyzed using WHO Epi-info software version 3.5.4.

\section{Results}

Out of the 400 preschool children included in the present study, 85 children were reported to be suffering from some morbidity thereby making a prevalence rate of $21.25 \%$.

Acute respiratory infection (ARI) was the single most common morbidity affecting majority i.e. 67
(16.75\%) followed by fever in only about $6(1.5 \%)$ of children as seen in Fig. 1.

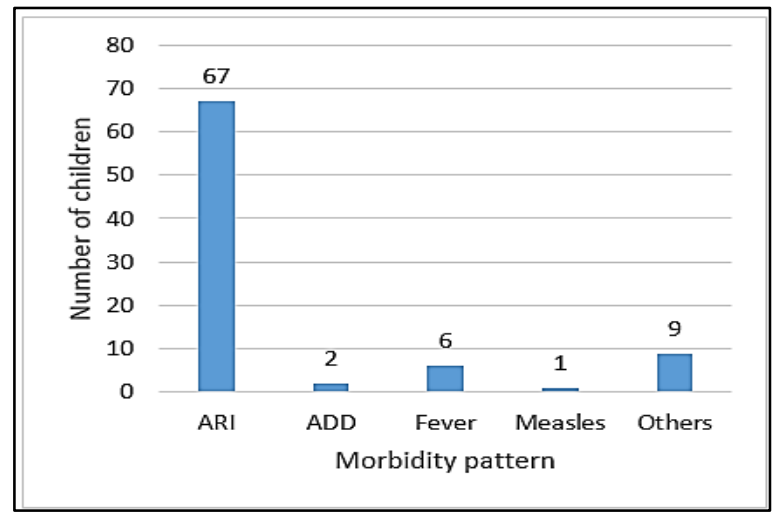

Fig 1: Distribution of study subjects according to their morbidity

Table 1 shows the association of morbidity prevalence among study subjects with certain variables related to child. It is evident from the table that the prevalence of morbidity was more in female children compared to males, but this was not found to be statistically significant $(\mathrm{P}>0.05)$. Morbidity was found to be directly proportional to the age group of the child except for the age group of 48-59 months which had the least prevalence and the association between the prevalence of morbidity and age was found to be statistically significant $(\mathrm{P}<0.05)$. Similarly there was significant association between the prevalence of morbidity among study children and the number of siblings they had $(\mathrm{P}<0.05)$. However, the present study could not find any significant association between the prevalence of morbidity and birth order and immunization status of the child as evident from the table $(\mathrm{P}>0.05)$

Table 1: Prevalence of morbidity among study subjects according to certain variables of the child $(n=400)$.

\begin{tabular}{|c|c|c|c|c|c|}
\hline \multirow[t]{2}{*}{ Variable } & \multirow[t]{2}{*}{ Classification } & \multirow{2}{*}{$\begin{array}{c}\text { Children } \\
\text { Observed N }\end{array}$} & \multicolumn{2}{|c|}{ Morbidity status n (\%) } & \\
\hline & & & Present & Absent & \\
\hline \multirow[t]{2}{*}{ Gender } & Male & 190 & $33(17.4)$ & $157(82.6)$ & \multirow{2}{*}{$\begin{array}{l}\chi^{2}=3.258 \\
P=0.071\end{array}$} \\
\hline & Female & 210 & $52(24.8)$ & $158(75.2)$ & \\
\hline \multirow{4}{*}{ Age (months) } & $12-23$ & 112 & $19(17)$ & $93(83)$ & \multirow{4}{*}{$\begin{array}{c}\chi^{2}=11.722 \\
P=0.008\end{array}$} \\
\hline & $24-35$ & 101 & $21(20.8)$ & $80(79.2)$ & \\
\hline & $36-47$ & 97 & $32(33)$ & $65(67)$ & \\
\hline & $48-59$ & 90 & $13(14.4)$ & $77(85.6)$ & \\
\hline \multirow{3}{*}{ Birth order } & First & 192 & $40(20.8)$ & $152(79.2)$ & \multirow{3}{*}{$\begin{array}{l}\chi^{2}=0.535 \\
P=0.765\end{array}$} \\
\hline & Second & 134 & $27(20.1)$ & $107(79.9)$ & \\
\hline & Third \& above & 74 & $18(24.3)$ & $56(75.7)$ & \\
\hline \multirow{3}{*}{$\begin{array}{l}\text { Number of } \\
\text { siblings }\end{array}$} & None & 87 & $10(11.5)$ & $77(88.5)$ & \multirow{3}{*}{$\begin{array}{l}\chi^{2}=6.358 \\
P=0.042\end{array}$} \\
\hline & One & 206 & $50(24.3)$ & $156(75.7)$ & \\
\hline & Two \& above & 107 & $25(23.4)$ & $82(76.6)$ & \\
\hline \multirow{2}{*}{$\begin{array}{l}\text { Immunization } \\
\text { status }\end{array}$} & Complete & 376 & $83(22.1)$ & $293(77.9)$ & \multirow{2}{*}{$\begin{array}{l}\chi^{2}=2.546 \\
P=0.111\end{array}$} \\
\hline & Partial & 24 & $2(8.3)$ & $22(91.7)$ & \\
\hline
\end{tabular}


Table 2 shows the association of morbidity among study subjects with certain Social and Environmental factors. The present study could not find any significant association between the prevalence of morbidity among preschool children and the literacy and employment status of their mothers $(P>0.05)$. However, morbidity was directly proportional to the paternal literacy and this was found to be statistically significant $(\mathrm{P}<0.05)$.
The prevalence of morbidity was more in children belonging to Hindu religion, more in Scheduled caste/ Scheduled tribe (SC/ST) children among Hindus, more in children belonging to other than nuclear families and more in children residing in houses having toilets in the present study. However, none of the above mentioned factors showed significant association with morbidity $(\mathrm{P}$ $>0.05)$.

Table 2: Prevalence of morbidity among study subjects according to certain Social and Environmental

\begin{tabular}{|c|c|c|c|c|c|}
\hline \multirow[t]{2}{*}{ Variable } & \multirow[t]{2}{*}{ Classification } & \multirow{2}{*}{$\begin{array}{c}\text { Children } \\
\text { Observed N }\end{array}$} & \multicolumn{2}{|c|}{ Morbidity status n (\%) } & \\
\hline & & & Present & Absent & \\
\hline \multirow{3}{*}{$\begin{array}{l}\text { Literacy of } \\
\text { mother } \\
(\mathrm{n}=\mathbf{4 0 0})\end{array}$} & Illiterate & 37 & $5(13.5)$ & $32(86.5)$ & \multirow{3}{*}{$\begin{array}{l}\chi^{2}=2.878 \\
P=0.237\end{array}$} \\
\hline & $\begin{array}{l}\text { Literate but below } \\
\text { High school }\end{array}$ & 157 & $30(19.1)$ & $127(80.9)$ & \\
\hline & $\begin{array}{l}\text { High school \& } \\
\text { above }\end{array}$ & 206 & $50(24.3)$ & $156(75.7)$ & \\
\hline \multirow{2}{*}{$\begin{array}{l}\text { Employment } \\
\text { status of mother } \\
(\mathrm{n}=400)\end{array}$} & Housewife & 351 & $79(22.5)$ & $272(77.5)$ & \multirow{2}{*}{$\begin{array}{l}\chi^{2}=2.706 \\
P=0.100\end{array}$} \\
\hline & Employed & 49 & $6(12.2)$ & $43(87.8)$ & \\
\hline \multirow{3}{*}{$\begin{array}{l}\text { Literacy of } \\
\text { father }^{*} \\
(\mathbf{n}=\mathbf{3 9 8})\end{array}$} & Illiterate & 54 & $7(13)$ & $47(87)$ & \multirow{3}{*}{$\begin{array}{l}\chi^{2}=7.911 \\
P=0.019\end{array}$} \\
\hline & $\begin{array}{l}\text { Literate but below } \\
\text { High school }\end{array}$ & 130 & $21(16.2)$ & $109(83.8)$ & \\
\hline & $\begin{array}{l}\text { High school \& } \\
\text { above }\end{array}$ & 214 & $57(26.6)$ & $157(73.4)$ & \\
\hline \multirow{3}{*}{$\begin{array}{l}\text { Religion } \\
(n=400)\end{array}$} & Hindu & 342 & $74(21.6)$ & $268(78.4)$ & \multirow{3}{*}{$\begin{array}{l}\chi^{2}=0.430 \\
P=0.806\end{array}$} \\
\hline & Muslim & 57 & $11(19.3)$ & $46(80.7)$ & \\
\hline & Christian & 1 & $0(0)$ & $1(100)$ & \\
\hline \multirow{2}{*}{\begin{tabular}{|l|} 
Caste $^{\dagger}$ \\
$(\mathrm{n}=342)$
\end{tabular}} & SC/ST & 146 & $35(24)$ & $111(76)$ & \multirow{2}{*}{$\begin{array}{l}\chi^{2}=0.819 \\
P=0.365\end{array}$} \\
\hline & Others & 196 & 39 (19.9) & $157(80.1)$ & \\
\hline \multirow{2}{*}{$\begin{array}{l}\text { Type of Family } \\
(\mathrm{n}=400)\end{array}$} & Nuclear & 148 & $26(17.6)$ & $122(82.4)$ & \multirow{2}{*}{$\begin{array}{l}\chi^{2}=1.904 \\
P=0.168\end{array}$} \\
\hline & Others & 252 & $59(23.4)$ & $193(76.6)$ & \\
\hline \multirow{2}{*}{$\begin{array}{l}\text { Availability of } \\
\text { toilet in house } \\
(\mathrm{n}=400)\end{array}$} & Present & 301 & $69(22.9)$ & $232(77.1)$ & \multirow{2}{*}{$\begin{array}{l}\chi^{2}=2.036 \\
P=0.154\end{array}$} \\
\hline & Absent & 99 & $16(16.2)$ & $83(83.8)$ & \\
\hline
\end{tabular}

\section{Discussion}

The prevalence of morbidity in the present study was found out to be $21.25 \%$ which is similar to the findings of another study done in the same district. ${ }^{6}$ Many other studies done in different parts of the country ${ }^{1,2,4,7-11}$ however have found out even higher prevalence of morbidity among their study subjects which could be due to geographical differences in the study settings, differences in the profile of study population, differences in the study periods, differences in the method / tools of data collection etc. The most common morbidity affecting the children in the present study was Acute respiratory infections similar to the findings of many other studies..$^{3,4,6-8,12,13}$ On the contrary few studies ${ }^{1,2,11,14}$ have found diarrhea as the most common morbidity and a couple of others ${ }^{9,15}$ have found anemia.

The present study could not find any significant association between the prevalence of morbidity and the gender of the child unlike few other studies. ${ }^{1,3,4,7}$
However age of the child was found to be significantly associated with morbidity similar to the findings of other studies. ${ }^{1,6,12}$ The prevalence of morbidity was significantly more in children who had at least one sibling against those who had none in the present study which confirms the findings of a longitudinal study done in Kolkata by Sucharita Maji et al. ${ }^{16}$

Neither literacy nor employment status of mothers have been found to have impact on morbidity among their children as per the present study findings. On the contrary a study by Mohan Shinde et $\mathrm{al}^{4}$ in Madhya Pradesh and Nitin Joseph et al ${ }^{17}$ in Karnataka have found inverse relationship between morbidity prevalence and Maternal literacy. Paternal literacy however has been found to be significantly associated with morbidity prevalence among children similar to the findings of a study by Mane $\mathrm{V}$ et al. done in same district of Karnataka. ${ }^{6}$ Any other factors studied like religion, caste, type of family or availability of toilet in the house were 
found to have no impact on the morbidity prevalence in the present study.

\section{Conclusion}

More than one in five preschool children was found to be suffering from some morbidity and Acute respiratory infections were the most common infections affecting majority of them. Morbidity was found to be significantly associated with age, number of siblings and the paternal literacy of the child in our study. The present study findings may have important implications for policy-makers and planners seeking to improve child health.

\section{References}

1. Ishore K, Bhattacherjee S, Das DK. Morbidity among tribal under-five children of tea garden areas in a block of Darjeeling District, West Bengal: A Cross-Sectional Study. J Clin DiagnRes 2015;9:LC01-3.

2. Vyas S, Kandpal S, Semwal J, Deepshikha. A study on morbidity profile and associated risk factors in a rural area of Dehradun. J Clin Diagn Res 2014;8:JC01-4.

3. Gupta S, Jamwal DS, Kumar D, Gupta SK. Morbidity among under five children in a Rural area of Jammu. $J K$ Science 2012;4(2):85-88.

4. Shinde M, Joshi A, Trivedi A. Morbidity profile of preschool children in rural area of central Madhya Pradesh. Int J Community Med Public Health 2015;2:298-301.

5. "Under-Five Mortality" Available at URL: http://www.who.int/gho/child_health/ mortality/mortality_under_five_text/en/. Accessed on $30^{\text {th }}$ October 2015.

6. Mane V, Naik TB, Mallappa O, Ambure O. Morbidity Pattern and Its Associated Factors among Preschool Children: A Cross-Sectional Study. Int J Prevent Public Health Sci 2016;1(5):12-15.

7. Ukey UU, Chitre DS. Morbidity profile of preschool children in an urban slum area. Indian Med Gaz 2012;45:300-4.

8. Singh B, Ghosh A, Singh A. Health problems in children and associated remedial measures in Punjab, India. Int $J$ Med Sci Public Health 2015;4:173-8.

9. Narkhede V, Sinha U, Bhardwaj SD, Pitale S. Morbidity Profile in Under Five Children in Urban Slum Area of Nagpur. Natl J Community Med 2012; 3(3):442-6.

10. Khalid M, Kumari R, Mohan U, Manar MK, Singh VK. Morbidity profile of preschool children below poverty line families of Lucknow District, North India. Int $J$ Adv Res 2014;2:627-34.

11. Santoshkumar A, Sunilkumar D, Ashok NC, Koppad R. Protein energy malnutrition and its association with immunization status and common morbidities among 1-5 year aged children in southern part of India, Mysore. Int $J$ Cur Res Rev 2013;5(2):105-10.

12. Singh HN, Devi HS, Singh YM. Study on morbidity among under five children of a rural area of Manipur, Thanga: A cross sectional study. J Evol Med Dent Sci 2013;2:2643-7.

13. Sarkar R, Sivarathinaswamy P, Thangaraj B, Sindhu KN, Ajjampur SS, Muliyil J, et al. Burden of childhood diseases and malnutrition in a semiurban slum in southern India. BMC Public Health 2013;13:87.

14. Srivastva DK, Tripathi D, Gour N, Jain PK, Singh CM, Srivastava AK, et al. Morbidity profile of under five children in urban slums of Etawah district. Indian J Community Health 2012;24:153-7.

15. Kubde SR, Kokiwar PR. A comparative study of morbidity pattern among children of 0-6 years in ICDS and non ICDS area. MRIMS J Health Sci 2013; 1:30-3.

16. Maji S, Ray SK, Lahiri SK. A longitudinal study of morbidity pattern and nutritional status of under five children in a slum community of Kolkata. IOSR- JDMS 2014;13(8):1-5.

17. Joseph N, Naik VA, Mahantshetti NS, Unikrishnan B, Mallapur M, Kotian SM. Factors associated with morbidities among infants in three sub center areas of belgaum district of south India: A longitudinal study. Indian J Community Med. 2013;38(3):168-174. 